\title{
Developmental Gene Expression in the Human Fetal Pancreas
}

\author{
MARTIN I. MALLY, TIMO OTONKOSKI, ANA D. LOPEZ, AND ALBERTO HAYEK \\ The Lucy Thorne Whittier Children's Center, The Whittier Institute for Diabetes and \\ Endocrinology, La Jolla, California 92037
}

\section{ABSTRACT}

Differential developmental regulation of pancreasspecific genes has not been reported for the human fetal pancreas. We have therefore undertaken a systematic, quantitative analysis of the transcriptional levels of various genes in the human pancreas at different stages of fetal and postnatal development. Using sensitive ribonuclease protection assays, in situ hybridization, and the polymerase chain reaction, our results indicate the following: 1) Transcriptional levels of insulin and amylin remain lower in the fetal than in the adult pancreas, whereas glucagon and somatostatin mRNA levels are consistently greater after 14 wk gestation than postnatally. These results are in agreement with previous immunohistochemical studies of these gene products. 2) The reg gene exhibits a 20 -fold increase in mRNA levels after 16 wk gestation. The gene is expressed exclusively in the acinar cells and does not colocalize with insulin. This restricted exocrine expression does not indicate a direct role for the reg gene in islet development. 3) Glucose transporter 2 and glucokinase mRNA are detectable as early as $13 \mathrm{wk}$ gestation and remain low throughout development. Glucose transporter 1 reaches adult transcriptional levels by 18 wk gestation. The early detection of glucose transporter 2 and glucokinase implies that lack of expression of these "glucose sensor" genes does not account for the known insensitivity of the fetal $\beta$-cells to glucose. (Pediatr Res 36: 537-544, 1994)

\author{
Abbreviations \\ reg gene, regenerating gene \\ GLUT-1 or -2, glucose transporter 1 or 2 \\ RT-PCR, reverse-transcription polymerase chain reaction \\ RNase, ribonuclease \\ UTR, untranslated region \\ nt, nucleotide \\ tRNA, transfer RNA
}

The developing human fetal pancreas has been the subject of many immunohistochemical and ultrastructural studies. The appearance and frequency of the different endocrine cell types vary during development, and it is now generally accepted that the $\alpha$-cells appear first at approximately $8-9 \mathrm{wk}$ gestation, followed sequentially by the $\beta$-cells, $\delta$-cells, and PP-cells. By 9-10 wk gestation, all four pancreatic endocrine cell populations have been detected by immunofluorescence, immunocytochemistry, and electron microscopy (1-4).

Studies in other systems, including the mouse pancreas, have shown that temporal patterns of gene expression can differ significantly from those detected by techniques that determine the presence of protein. Using a combination of embryo microdissection and the polymerase chain reaction, Gittes and Rutter (5) observed that

Received February 22, 1994; accepted May 28, 1994.

Correspondence and reprint requests: Martin I. Mally, Ph.D., The Whittier Institute for Diabetes and Endocrinology, 9894 Genesee Ave., La Jolla, CA 92037.

Supported by NIDDK grant R01-DK39087 and grants from the Herbert $O$. Perry Fund and the Deutz Family. transcription of the endocrine genes occurred before detectable morphogenesis in the mouse. It was suggested that this "premorphogenetic phase" of organogenesis may represent the beginning of the endocrine cell lineages. A similar situation may also occur in the human pancreas.

Insulin release from the pancreatic islets is controlled by the uptake and metabolism of glucose by the $\beta$-cells. Although insulin is present in the human fetal pancreas from $10 \mathrm{wk}$ gestation, insulin release remains practically unresponsive to glucose stimulation until birth (6). The cellular uptake of glucose across the plasma membrane is accomplished by membrane-associated carrier proteins, termed glucose transporters. GLUT-1 is the predominant isoform expressed in most fetal tissues, whereas GLUT-2 is the major isoform detected in adult pancreatic $\beta$-cells (7-9). It has been suggested that the glucose-sensing apparatus of $\beta$-cells consists of GLUT- 2 working in concert with glucokinase, the enzyme that catalyzes the rate-limiting step in glucose metabolism $(8,10)$. Expression of the genes encoding GLUT-1, GLUT-2, and glucokinase has not been reported during human fetal pan- 
creatic development; therefore, it was important to examine their expression levels in light of the reported glucose insensitivity of the fetal $\beta$-cell.

Since the identification of the reg gene in adult rat islets undergoing regeneration (11), its physiologic role has remained unclear, with evidence for both exocrine and endocrine involvement (12-15). Studies on the expression of the reg gene in the human fetal pancreas may help clarify its role in pancreatic development.

This study was undertaken to obtain a more complete understanding of pancreatic ontogeny as it relates to the transcriptional regulation of pancreatic genes. We present detailed quantitative data on the developmental regulation of the steady state levels of the mRNA encoding the islet hormones, as well as other pancreas- or isletspecific proteins in the human fetal and postnatal pancreas.

\section{METHODS}

Tissue procurement. Intact human fetal pancreata at 12-24 wk gestational age were obtained through nonprofit organ procurement centers (Advanced Bioscience Resources, Oakland, CA; International Institute for the Advancement of Medicine, Exton, PA). Informed consent for tissue donation was obtained by the procurement centers. Gestational age was determined by several criteria, including biparietal diameter, femur length, and fetal foot measurements. Pancreatic tissues arrived in our laboratory after periods of $5 \mathrm{~min}$ and $24 \mathrm{~h}$ of warm and cold ischemia, respectively. Tissues were shipped on ice in RPMI 1640 medium (Irvine Scientific, Irvine, CA) containing $10 \%$ pooled normal human serum and antibiotics $(100 \mathrm{U} / \mathrm{mL}$ penicillin, $0.1 \mathrm{mg} / \mathrm{mL}$ streptomycin, and $1 \mu \mathrm{g} / \mathrm{mL}$ amphotericin B). Upon arrival, pancreatic tissues were carefully dissected free of extraneous tissue, immediately snap-frozen in liquid nitrogen, and stored at $-70^{\circ} \mathrm{C}$. Adult pancreatic tissue was kindly provided by Dr. J. Chang (Immune Response Corp., Carlsbad, CA). Adult pancreas and liver RNA were obtained from Clontech Laboratories (Palo Alto, CA). A pancreatic section obtained at autopsy (4 h postmortem) of an 11-mo-old child who died of a brain tumor was provided by Children's Hospital of San Diego. Adult islets were kindly provided by Dr. C. Ricordi (University of Pittsburgh Transplant Institute, Pittsburgh, PA).

RNase protection assay probes. All probes used for the RNase protection assay were of human origin and were subcloned into the pGEM (Promega, Madison, WI) or pBluescript (Stratagene, La Jolla, CA) riboprobe vectors by standard procedures (16). The insulin probe (provided by Dr. P. Miettinen, University of Helsinki, Finland) was a 262-bp fragment corresponding to amino acids $1-87$ in preproinsulin mRNA (17). The glucagon probe (provided by Dr. D. Drucker, Toronto General Hospital, Toronto, Ontario, Canada) encompassed 5'UTR sequences and amino acids $1-117$ in preproglucagon mRNA (18). Somatostatin (ATCC, Rockville, MD) was detected by a subclone representing bp 1245-1480 in the genomic sequence (19). The cyclophilin probe (provided by Dr. D. Bergsma, SmithKline Beecham Pharmaceuticals, King of Prussia, PA) corresponded to 5'UTR sequences and amino acids $1-28$ in the full-length cDNA sequence (20). Amylin was detected by a subclone representing a portion of the 5'UTR and amino acids 1-66 in the cDNA sequence (provided by Dr. D. Steiner, Howard Hughes Medical Institute, University of Chicago, Chicago, IL). The amylase probe (ATCC) was a genomic subclone composed of a portion of intron 1 , the entire exon 1 , and part of intron $2(21)$. The reg gene probe (provided by $\mathrm{Dr}$. H. Okamoto, Tohoku University School of Medicine, Sendai, Japan) corresponded to amino acids 115-165 and 3'UTR sequences (11). The GLUT-1 probe (ATCC) consisted of 5'UTR sequences and amino acids 1-93 in the cDNA sequence (22). Plasmid constructs were linearized with the appropriate restriction enzymes and gel purified using the QIAEX gel extraction kit (QIAGEN Inc., Chatsworth, CA). Radiolabeled antisense probes were generated by in vitro transcription in the presence of $\left.{ }^{32} \mathrm{P}\right]$ uridine triphosphate using the appropriate RNA polymerase (23). Protected probe lengths are as follows: insulin, $262 \mathrm{nt}$; glucagon, $389 \mathrm{nt}$; somatostatin, $236 \mathrm{nt}$; cyclophilin, $135 \mathrm{nt}$; amylin, $267 \mathrm{nt}$; amylase, $214 \mathrm{nt}$; reg, $180 \mathrm{nt}$; and GLUT-1, 294 nt.

RNA isolation and analysis. Total cytoplasmic RNA was isolated by the acid guanidinium thiocyanate method (24) and quantitated spectrophotometrically. Transcriptional analyses were performed using a multiprobe RNase protection assay $(23,25)$. Total RNA $(0.4-5 \mu \mathrm{g})$ was hybridized for $18 \mathrm{~h}$ at $56^{\circ} \mathrm{C}$ with ${ }^{32} \mathrm{P}$-labeled antisense RNA probes in $40 \mathrm{mmol} / \mathrm{L}$ PIPES buffer ( $\mathrm{pH}$ 6.4) containing $400 \mathrm{mmol} / \mathrm{L} \mathrm{NaCl}, 1 \mathrm{mmol} / \mathrm{L}$ EDTA, and $80 \%$ formamide. Yeast tRNA $(10 \mu \mathrm{g})$ was included as a negative control. Excess probe and nonhomologous RNA sequences were removed by RNase digestion $(50 \mu \mathrm{g} / \mathrm{mL}$ RNase $A$ and $50 \mathrm{U} / \mathrm{mL}$ RNase T1) in $10 \mathrm{mmol} / \mathrm{L}$ Tris- $\mathrm{HCl}$ (pH 7.5), $300 \mathrm{mmol} / \mathrm{L} \mathrm{NaCl}$, and $5 \mathrm{mmol} / \mathrm{L}$ EDTA for $1 \mathrm{~h}$ at $30^{\circ} \mathrm{C}$, followed by treatment with $200 \mu \mathrm{g} / \mathrm{mL}$ proteinase $\mathrm{K}$ in $2 \% \mathrm{SDS}$ for $30 \mathrm{~min}$ at $37^{\circ} \mathrm{C}$. Samples were extracted with phenol/chloroform, ethanol precipitated with $10 \mu \mathrm{g}$ of yeast tRNA as carrier, and dissolved in formamide sample buffer. The protected, doublestranded hybrids were separated by denaturing PAGE, followed by autoradiography on Kodak XRP film to visualize the target RNA. Quantitation was performed by scanning densitometry (LKB UltroScan XL Laser) and integrated using GelScan XL software (Pharmacia LKB, Piscataway, NJ). Peak heights were used to quantitate transcriptional levels. Different exposure times were used to ensure that all signals fell within the linear range of the densitometer. The probe-specific mRNA signals were normalized to the cyclophilin signal in each sample to account for differences in sample loading between lanes.

Tissue preparation for in situ hybridization and immunohistochemistry. A 24-wk gestational age fetal pancreas was fixed in $4 \%$ paraformaldehyde in $\mathrm{PBS}\left(\mathrm{pH} \mathrm{7.4)}\right.$ at $4^{\circ} \mathrm{C}$ for 
$4 \mathrm{~h}$. After dehydration, the tissue was embedded in paraffin and 5- $\mu \mathrm{m}$ sections were mounted on Superfrost/Plus slides (Fisher Scientific, Pittsburgh, PA). Consecutive sections were used for both in situ hybridization and immunohistochemistry.

In situ hybridization. Sense and antisense probes for both insulin and the reg gene were transcribed from cDNA in the presence of $\left[{ }^{35}\right.$ S]uridine triphosphate using the appropriate RNA polymerase. In situ hybridization was performed according to the method of Simmons et al. (26). Tissue sections were digested with proteinase $\mathrm{K}$ $(10 \mu \mathrm{g} / \mathrm{mL})$ for $30 \mathrm{~min}$ at $37^{\circ} \mathrm{C}$, acetylated for $10 \mathrm{~min}$ at room temperature, rinsed in $0.3 \mathrm{~mol} / \mathrm{L} \mathrm{NaCl}-30 \mathrm{mmol} / \mathrm{L}$ sodium citrate ( $\mathrm{pH} 7.0$ ), dehydrated, and air dried. Hybridization with the ${ }^{35} \mathrm{~S}$-labeled probes $\left(2-4 \times 10^{6} \mathrm{cpm} /\right.$ $\mathrm{mL}$ ) was performed at $55^{\circ} \mathrm{C}$ for $16 \mathrm{~h}$ in a buffer consisting of $50 \%$ formamide, $0.3 \mathrm{~mol} / \mathrm{L} \mathrm{NaCl}, 10 \mathrm{mmol} / \mathrm{L}$ Tris $(\mathrm{pH}$ $8.0), 1 \mathrm{mmol} / \mathrm{L}$ EDTA, $1 \times$ Denhardt's solution $(0.02 \%$ each of Ficoll 400, polyvinylpyrrolidone, and BSA, Fraction V), $10 \%$ dextran sulfate, $50 \mathrm{mmol} / \mathrm{L}$ DTT, and 500 $\mu \mathrm{g} / \mathrm{mL}$ each of yeast tRNA and Torula yeast RNA. Sections were digested with RNase $A$ at $37^{\circ} \mathrm{C}$ for $30 \mathrm{~min}$, washed under high-stringency conditions, dehydrated in ethanol, and dried. Slides were coated with Kodak NTB-2 autoradiograph emulsion and exposed in sealed boxes at $4^{\circ} \mathrm{C}$ for $10 \mathrm{~d}$. After development in Kodak D-19 for $3.5 \mathrm{~min}$, the slides were rinsed, fixed, and counterstained with hematoxylin and eosin. Hybridization signals were analyzed using bright- and dark-field microscopy.

Immunohistochemistry. Paraffin sections $(5 \mu \mathrm{m})$ from the 24-wk gestational age fetal pancreas were stained for insulin using the immunoalkaline phosphatase technique (27). Briefly, deparaffinized and rehydrated sections were blocked with $10 \%$ goat serum for $10 \mathrm{~min}$, washed, and incubated with polyclonal guinea pig anti-porcine insulin antibody (Chemicon, El Segundo, CA) at a 1:100 dilution for $3 \mathrm{~h}$. After washing, sections were incubated for $20 \mathrm{~min}$ with a biotinylated goat anti-rabbit antibody that crossreacts with guinea pig antibody (BioGenex, San Ramon, CA), washed, and incubated with streptavidin alkaline phosphatase for $20 \mathrm{~min}$. Immunoreactivity was visualized using Fast Red (Sigma Chemical Co., St. Louis, $\mathrm{MO})$ as chromogen, then sections were washed and counterstained with hematoxylin.

$\boldsymbol{R T}$-PCR. Total RNA (1-2 $\mu \mathrm{g})$ from fetal pancreatic tissues (13 wk gestation), adult islets, and adult liver was reverse transcribed into cDNA with an oligo $d(T)$ primer according to manufacturer's recommendations (GeneAmp RNA PCR kit, Perkin-Elmer Cetus, Norwalk, CT). The samples were divided in two and amplified with GLUT-2 and glucokinase primers. Primers specific for human GLUT-2 and islet-specific glucokinase were as previously described (28-30) and were designed to span intron sequences to distinguish amplification products resulting from any contaminating genomic DNA sequences present in the RNA preparations. Amplifications were performed in a PowerBlock temperature cycler (Ericomp, San Diego, CA). Samples were initially denatured at $94^{\circ} \mathrm{C}$ for $1 \mathrm{~min}$. Cycling parameters ( 45 cycles) were as follows: denaturation at $94^{\circ} \mathrm{C}$ for $1 \mathrm{~min}$, annealing at $50^{\circ} \mathrm{C}$ for $1 \mathrm{~min}$, and extension at $72^{\circ} \mathrm{C}$ for $1 \mathrm{~min}$ (GLUT-2), or annealing and extension simultaneously at $72^{\circ} \mathrm{C}$ for $1 \mathrm{~min}$ for glucokinase. A final extension at $72^{\circ} \mathrm{C}$ for $7 \mathrm{~min}$ was performed. Portions $(10 \%)$ of the amplified products were analyzed by electrophoresis, in the presence of ethidium bromide, on 3\% NuSieve GTG/1\% agarose gels (FMC, Rockland, ME).

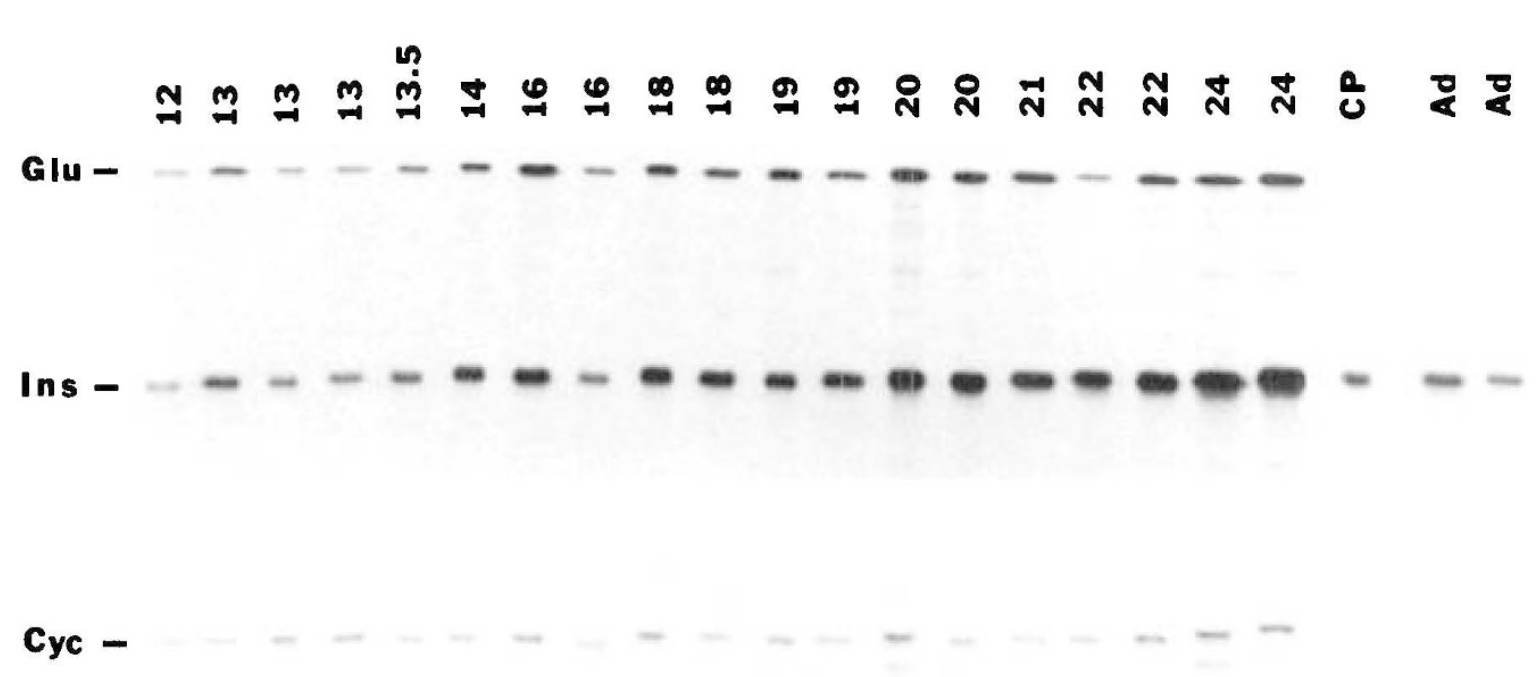

Figure 1. RNase protection analysis of hormone transcripts in a series of fetal and postnatal pancreata. Total RNA (400 ng) was hybridized simultaneously to antisense riboprobes for glucagon $(G l u)$, insulin $(I n s)$, and cyclophilin $(C y c)$ for $18 \mathrm{~h}$ at $56^{\circ} \mathrm{C}$ as described in Methods. Lanes for fetal tissue samples are identified by their gestational ages, in wk (12-24); $C P$, RNA from an 11-mo-old child; $A d$, adult pancreas; tRNA, yeast tRNA (used as a negative control). Protected fragments for glucagon ( $389 \mathrm{nt})$, insulin ( $262 \mathrm{nt})$, and cyclophilin (135 $\mathrm{nt}$ ) are indicated. Exposure times were $4 \mathrm{~h}$ for glucagon and insulin and $16 \mathrm{~h}$ for cyclophilin. Extended exposure times were required to detect glucagon transcripts in the 11 -mo-old and adult pancreas samples. 


\section{RESULTS}

Pancreatic hormone expression. Transcriptional expression of the genes encoding insulin or glucagon (Fig. 1) and somatostatin (Fig. 2A) were examined in a series of human fetal pancreata, ranging in gestational ages from 12-24 wk, using a multiprobe RNase protection assay. Quantitation of the hormone-specific mRNA was performed by scanning densitometry, normalizing the probespecific hybridized signal to the signal from the ubiquitous housekeeping gene cyclophilin (Table 1). The absence of any hybridized signals in the negative control (yeast tRNA) indicates the specificity of the assay. Insulin transcriptional levels continued to increase through gestation, with 3- to 5-fold more insulin mRNA present at 24 wk compared with $12 \mathrm{wk}$, yet remained lower than levels found in the adult pancreas (Table 1). In contrast, glucagon transcriptional levels peaked at approximately 20 wk gestational age and remained approximately 3 -fold greater than adult levels. Somatostatin mRNA levels were consistently greater after $14 \mathrm{wk}$ gestation than adult levels, which were barely detectable using equivalent RNA amounts (Table 1).

Amylin and amylase gene expression. Because amylin is cosecreted with insulin in the adult pancreas in response to glucose, it was of interest to determine its expression pattern throughout fetal development. The levels of amylin transcripts were fairly constant, as opposed to the gradual increase in insulin transcripts, throughout the gestational ages examined. An amylin transcript was initially seen at 13 wk gestational age and did not vary considerably throughout development (Fig. 2B). Amylin mRNA levels at 24 wk gestational age were approximately 10-fold lower than adult levels (Table 1). The pancreas from the 11-mo-old child had approximately 2 -fold more amylin transcripts than the adult pancreas. No hybridization signal was seen in the negative control.

Amylase transcripts were not detectable in any of the fetal pancreata analyzed (data not shown). The adult pancreas had approximately 4- to 5-fold more amylase transcripts than the 11-mo-old pancreas (Table 1).

Expression of the reg gene. Transcriptional expression of the islet reg gene showed low expression levels before 16 wk gestation. At this time, however, a sudden increase in reg mRNA levels was seen and continued to increase through 24 wk gestational age, at which point it reached levels comparable to those in the adult pancreas (Fig. $2 C$, Table 1), which were 2 -fold greater than those in the 11-mo-old pancreas.

Consecutive serial sections ( $5 \mu \mathrm{m}$ thick) from a $24-w k$ gestational age pancreas were hybridized to the insulin and reg gene riboprobes to identify their locations within the fetal pancreas. In situ hybridization with the insulin probe was used to identify the $\beta$-cells. Silver grains were specifically associated with scattered clusters of epithelial cells of variable sizes throughout the acinar tissue (Fig. 3A). Binding of the insulin sense probe showed very low background signals (Fig. $3 B$ ). The disseminated pat- tern of $\beta$-cells throughout the epithelial components of the fetal pancreas was also evident by immunostaining for insulin (Fig. 3C). The reg gene signal was entirely localized within the acinar cells of the fetal pancreas (Fig. $3 D-F)$. The clustering of specific hybridization signals resembled the pattern seen with the insulin probe. However, the reg gene signal was clearly more abundant than the insulin signal. Mesenchymal tissue and ductal epithelium were devoid of the reg gene signal. Consecutive sections hybridized with the control sense probe showed only low levels of nonspecific hybridization signals (not shown). To determine whether the insulin and reg genes are both expressed in the $\beta$-cells, consecutive serial tissue sections were hybridized to both probes. We found no evidence for colocalization of the insulin (Fig. 4A-C) and reg genes (Fig. $4 D-F$ ).

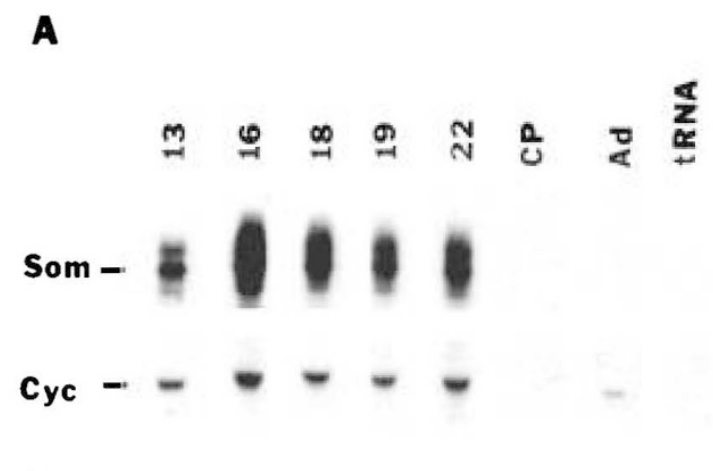

B
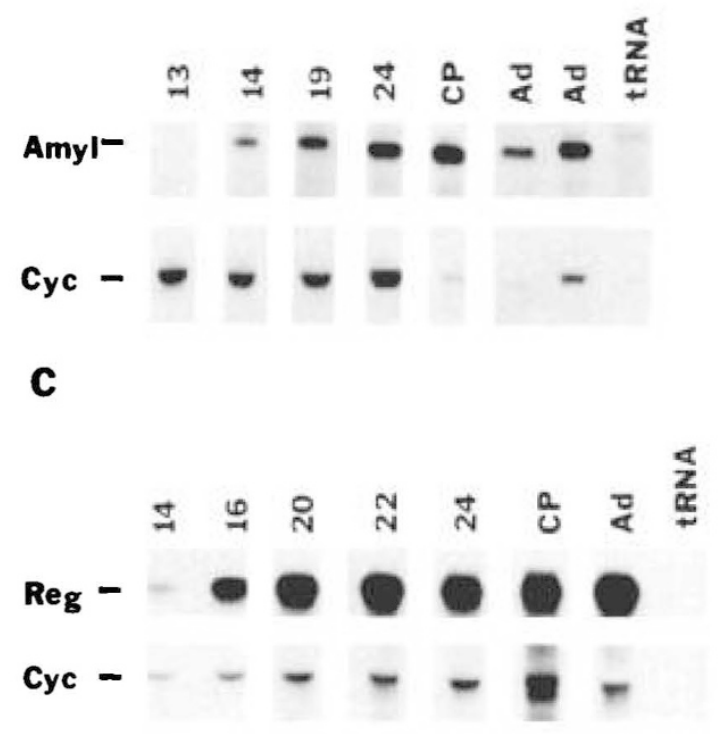

Figure 2. Detection of somatostatin, amylin, and reg gene transcripts in selected fetal and postnatal pancreata, demonstrating transcriptional modulation. RNase protection assays were performed on $400 \mathrm{ng}$ of total RNA for somatostatin (Som;A), $2 \mu \mathrm{g}$ for amylin (Amyl;B), and $400 \mathrm{ng}$ for reg gene $(\operatorname{Reg} ; C)$ as described above. Identification of lanes is the same as in Figure 1. Sizes of protected fragments are $236 \mathrm{nt}$ (somatostatin), $267 \mathrm{nt}$ (amylin), $180 \mathrm{nt}$ (reg gene), and $135 \mathrm{nt}$ (cyclophilin). Exposure times were as follows: $A, 54 \mathrm{~h}$ for somatostatin and $3 \mathrm{~d}$ for cyclophilin; $B, 4 \mathrm{~d}$ for amylin and $18 \mathrm{~h}$ for cyclophilin; and $C, 18 \mathrm{~h}$ for reg gene and cyclophilin. Longer exposure times were necessary to detect somatostatin transcripts in the 11-mo-old and adult pancreata. 
Table 1. Quantitation of appearance and modulation of various genes during development of human fetal pancreas*

\begin{tabular}{ccccccccc}
\hline Gestational age & $n$ & Insulin & Glucagon & Somatostatin & Amylin & Amylase & Reg & GLUT-1 \\
\hline $12 \mathrm{wk}$ & 1 & 0.38 & 0.25 & 0.12 & ND & ND & ND \\
$13 \mathrm{wk}$ & 3 & 0.34 & 0.32 & 0.23 & 0.02 & ND & 0.03 & 0.65 \\
$14 \mathrm{wk}$ & 2 & 0.58 & 0.49 & 0.28 & 0.41 & ND & 0.03 \\
$16 \mathrm{wk}$ & 2 & 0.63 & 0.83 & 1.00 & 0.09 & ND & 0.58 \\
$18 \mathrm{wk}$ & 2 & 0.88 & 0.78 & 1.64 & 0.08 & ND & 0.26 \\
$19 \mathrm{wk}$ & 2 & 0.84 & 0.94 & 1.11 & 0.47 & ND & 1.63 \\
$20 \mathrm{wk}$ & 3 & 1.40 & 1.44 & 1.56 & 0.26 & ND & 0.85 \\
$22 \mathrm{wk}$ & 2 & 1.35 & 0.59 & 1.74 & 0.80 & ND & 2.07 & 1.18 \\
$24 \mathrm{wk}$ & 2 & 1.59 & 0.86 & 1.79 & 0.59 & ND & 1.46 & 1.64 \\
$11 \mathrm{mo}$ & 1 & 2.50 & 0.17 & 0.10 & 11.25 & 1.78 & 0.75 & 0.70 \\
Adult & 2 & 2.40 & 0.40 & 0.43 & 5.67 & 8.23 & 1.56 & 1.35 \\
\hline
\end{tabular}

* Values are the averages of the densitometric scans of autoradiographs from RNase protection assays at each age of the indicated number ( $n$ ) of pancreata after normalization to the cyclophilin signal. Exposure times of the autoradiographs were varied to ensure that the signals were within the linear range of the densitometer. Each autoradiograph for all samples for a particular gene was scanned at the same exposure time. $N D$, not detected.

Glucose transporters and glucokinase expression. Expression of GLUT-1 transcripts in fetal pancreatic tissue was fairly constant through $16 \mathrm{wk}$ gestational age, at which time an approximate 2-fold increase was measured (Fig. 5; Table 1). The level of GLUT-1 transcripts at 18-24 wk gestation was similar to adult levels.

GLUT-2 transcripts were not detectable in any of the fetal or adult pancreata using the RNase protection assay, indicative of their low abundance in these tissues. Very low expression levels of glucokinase mRNA were detected in all the pancreatic samples analyzed, with no quantitative differences between fetal and adult tissues (data not shown). We therefore used the more sensitive technique, RT-PCR, to identify when transcription of these genes was first detectable (Fig. 6). Both GLUT-2 and the islet-specific glucokinase transcripts were detected using RT-PCR in the 13-wk fetal pancreata $(n=3)$, the youngest tissue samples tested. Human adult islets and liver were used as positive controls for GLUT-2. The specificity of the primers for the islet-specific glucokinase was borne out by the presence of an amplified product in the adult islet sample and the absence of any amplified product in the liver sample.

\section{DISCUSSION}

This study represents the first comprehensive report on comparative gene expression in the human fetal and postnatal pancreas, illustrating the developmental appearance and modulation of pancreas-specific genes. We used sensitive and highly specific RNase protection assays, in situ hybridization, and the polymerase chain reaction to detect and quantitate transcripts for endocrine and exocrine genes in the pancreas.

Because insulin release in the human fetal pancreas is unresponsive to glucose stimulation (6), it was important to determine whether this was due to a lack of transcription of the $\beta$-cell-specific glucose-sensing apparatus, namely, GLUT-2 and glucokinase. It has been suggested that inappropriate expression levels of these genes may be responsible for the abnormal insulin secretion observed in diabetic rats $(31,32)$ and in cell lines $(8,33)$. In normal $\beta$-cells, glucose transport capacity is in excess relative to glucose metabolism. In fact, it has been suggested that glucose transport into the $\beta$-cells needs to be reduced by at least $90 \%$ to interfere with glucose metabolism (34), supporting the notion that GLUT-2 plays only a permissive role in glucose sensing. Glucokinase has been proposed to be the $\beta$-cell "glucose sensor" $(35,36)$ because it catalyzes the rate-limiting step in glucose metabolism, which is a prerequisite for insulin secretion. Our RNase protection assay and RT-PCR data indicated the presence of GLUT-1, GLUT-2, and glucokinase transcripts in the 13-wk fetal pancreata, suggesting the presence of the respective functional proteins. Thus, it would appear that fetal $\beta$-cells are capable of transporting and phosphorylating glucose. However, we cannot rule out quantitative differences in these processes between the fetal and adult pancreas.

The role of the reg gene and its protein product is unclear in human fetal pancreatic development. The reg protein has been colocalized with insulin within the secretory granules of the regenerating $\beta$-cell (37). Based on these findings, and supported by later work with isolated rat islets (14), a role has been suggested for the reg gene in pancreatic islet growth and regeneration. However, other investigators have found the gene to be expressed in the exocrine portion of the adult pancreas $(12,15)$, where it encodes pancreatic stone protein, a major constituent of the exocrine pancreatic secretion (38). In the human fetal pancreas, the reg protein has previously been detected in the acinar cells, which were found to be weakly immunoreactive from 16 to 27 wk gestational age, at which point the staining became more intense, and markedly increased at birth (39). We observed very low expression of the reg gene before $16 \mathrm{wk}$ gestation, at which time a dramatic increase was seen. The levels remained high throughout gestation and reached levels comparable to those in the adult pancreas. Results of our in situ hybridization analysis are in agreement with the results of Miyaura et al. (13); that is, reg genes are entirely localized within the acinar tissue and are absent from mesenchymal, ductal, and islet cells. Additionally, 
reg transcripts did not colocalize with insulin in the $\beta$-cells, unlike the results of Terazono et al. (37). The barely detectable levels of reg mRNA in the 12- to 14-wk fetal pancreata, which already contain significant levels of the hormone transcripts, suggest that the reg gene does not play a direct role in early islet development. However, the dramatic increase in reg transcripts seen at 16 wk gestation, an age at which there is no significant expansion of the exocrine pancreatic compartment, may implicate the reg gene as being involved in the expansion of the islet mass. This is supported by Francis et al. (14), who showed an increase in reg mRNA expression associated with adult rat islet cell replication. Although the function of the reg gene product is unknown, prediction of its three-dimensional structure indicates significant homology with plant and animal lectins, suggesting a possible growth-promoting role $(40,41)$. Additional work
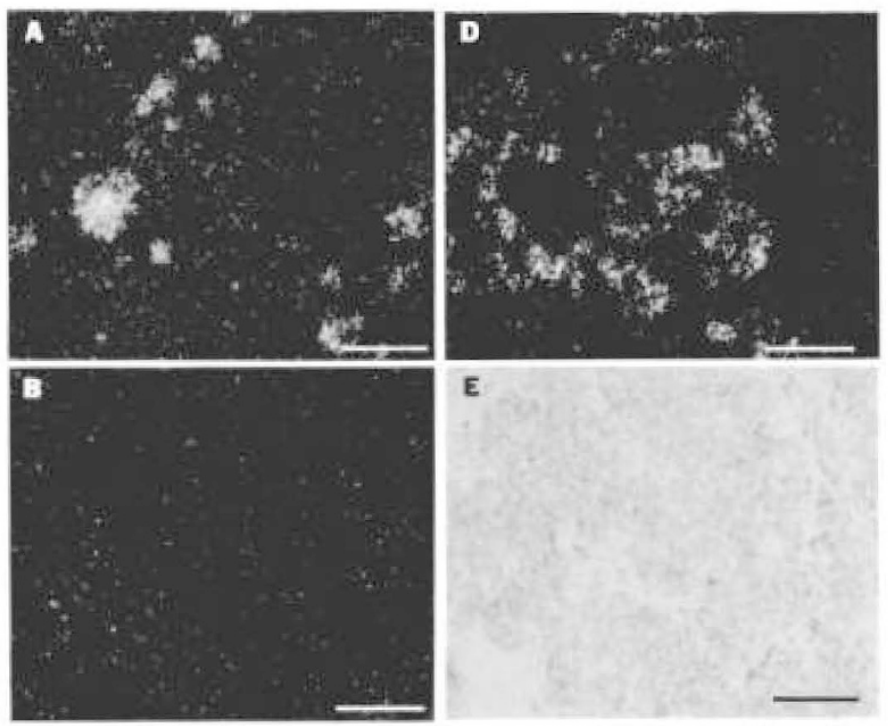

E
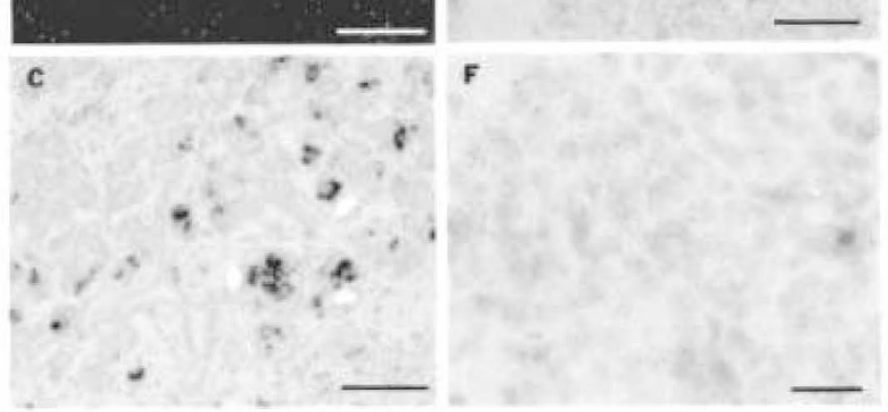

Figure 3. Localization of insulin and reg gene transcripts in a 24-wk gestational fetal pancreas using in situ hybridization. Dark-field micrographs of consecutive sections hybridized with the insulin antisense $(A)$ or control sense $(B)$ probes, identifying the $\beta$-cells in the fetal pancreas, are shown. Low magnification of the dark-field image $(A)$ shows specific association of silver grains with those epithelial cells expressing insulin mRNA. Note the lack of specific hybridization signal when the control sense cRNA probe was used $(B)$. Immunohistochemical staining for insulin $(C)$ demonstrates that the $\beta$-cells appear as small clusters of variable sizes scattered throughout the epithelial tissue (arrows). Low magnifications of dark- $(D)$ and bright-field $(E)$ images of a fetal pancreatic tissue section hybridized with the reg gene probe are shown. Note the clustering of specific signals associated with epithelial cells. $F$, Higher magnification of panel $\mathrm{E}$ showing those acinar cells expressing reg gene mRNA. Bars: $A-E, 100 \mu \mathrm{m} ; F, 20 \mu \mathrm{m}$. is needed to more clearly define the role of the reg gene in pancreatic development.

The levels of islet hormone transcripts (insulin, glucagon, and somatostatin) increased gradually throughout fetal development. Insulin mRNA levels in the fetal pancreas were found to be 2- to 6-fold lower compared with those in the postnatal pancreas, in contrast to glucagon and somatostatin mRNA levels, which were higher in the fetal than in the postnatal pancreas. These results are in agreement with previously published immunohistochemical and ultrastructural data $(1,3,4)$. The physiologic impact of the relatively high glucagon and somatostatin expression in the fetus is not clear. Transcription levels of the three hormones were similar in the pancreas of the 11-mo-old child and the adult, indicating that islet hormone expression matures completely during the first year of life.

In the normal adult pancreas, amylin is colocalized with insulin in the secretory granules $(42,43)$, where it is released concomitantly with insulin in response to a glu-

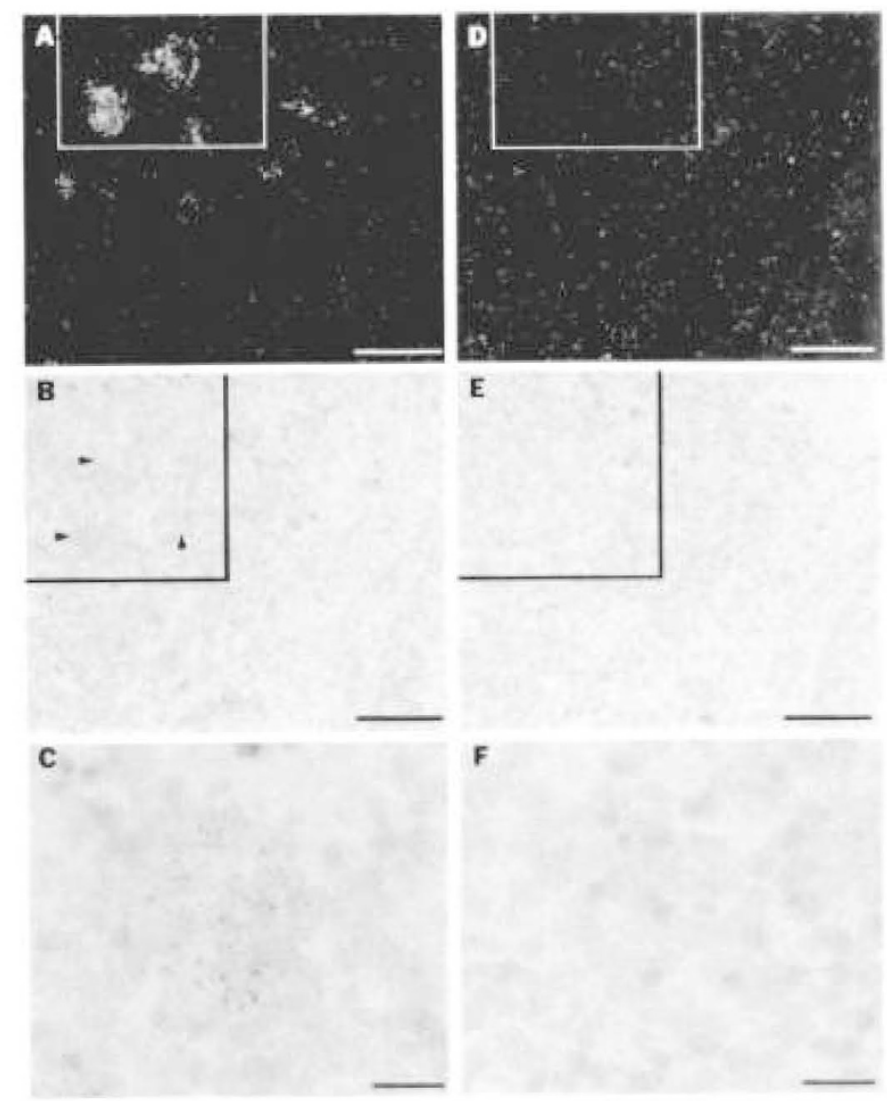

Figure 4. In situ hybridization analysis demonstrating that the insulin and reg genes do not colocalize in the fetal $\beta$-cells. Dark-field $(A$ and $D)$ micrographs of the same fields from consecutive tissue sections of a 24-wk gestational pancreas hybridized with the insulin $(A)$ or reg gene $(D)$ probes are shown. The boxed areas show the lack of reg gene expression in the insulin-expressing acinar cells. Panels $B$ and $E$ are the corresponding bright-field micrographs of panels $A$ and $D$, respectively, showing clusters of silver grains over groups of acinar cells (arrowheads). Panel $C$ is a higher magnification of panel $\mathbf{B}$ showing the specific association of the insulin probe with the acinar cells. Note the absence of reg gene expression $(F)$ in the same group of acinar cells that express insulin $(C)$. Bars: $A, B, D$, and $E, 100 \mu \mathrm{m} ; C$ and $F, 20 \mu \mathrm{m}$. 


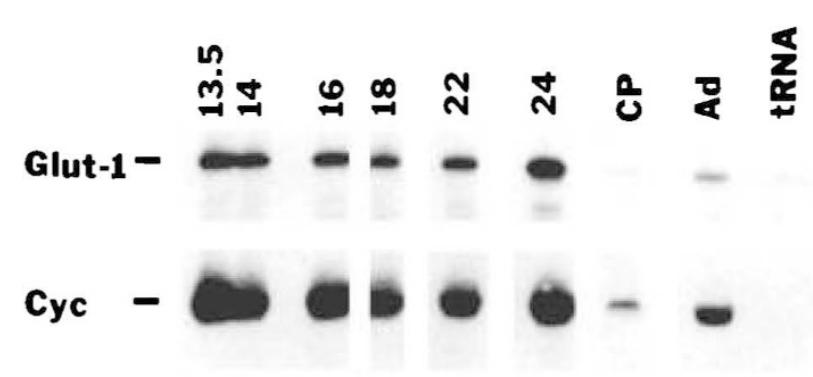

Figure 5. Detection of GLUT-1 transcripts in selected fetal and postnatal pancreata. Total RNA $(5 \mu \mathrm{g})$ was hybridized to the GLUT-1 riboprobe as described above. Identification of lanes is the same as in Figure 1. Representative fetal pancreas samples are shown, illustrating increased transcriptional levels in the latter gestational ages. Exposure times were $65 \mathrm{~h}$ for GLUT-1 and $17 \mathrm{~h}$ for cyclophilin $(\mathrm{Cyc})$.

$\begin{array}{lllllllllllllll}1 & 2 & 3 & 4 & 5 & 6 & 7 & 8 & 9 & 10 & 11 & 12 & 1314 & 15\end{array}$

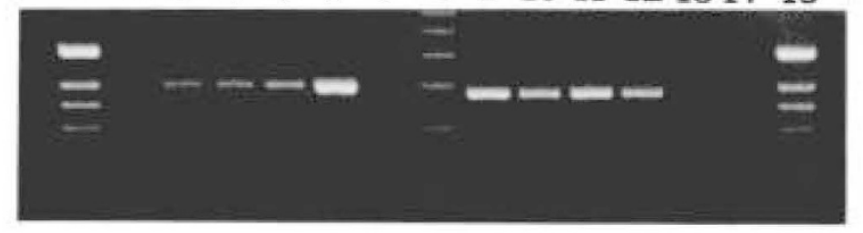

Figure 6. Detection of GLUT-2 and glucokinase transcripts using RTPCR in 13-wk gestational age pancreata. Total RNA $(1.3 \mu \mathrm{g})$ from three different 13-wk pancreata was reverse transcribed into cDNA; aliquots were then amplified as described in Methods, analyzed on agarose gels, and visualized by ethidium bromide staining. Molecular mass markers are a 1-kb DNA ladder (BRL, Grand Island, NY), lanes 1 and 15 , and a 100-bp ladder (GenSura Laboratories, San Diego, CA), lane 8. GLUT-2 (lanes 2-4; 398 bp) and glucokinase (lanes 9-11; $380 \mathrm{bp}$ ) transcripts were detected using RT-PCR in three different 13-wk fetal pancreata. Adult islets were used as positive controls for GLUT-2 (lane 5 ) and glucokinase (lane 12). Adult liver was used as a positive control for GLUT-2 (lane 6) and as a negative control for glucokinase (lane 13), illustrating the specificity of the polymerase chain reaction primers for the islet-specific glucokinase. Water was used as a negative control (lanes 7 and 14).

cose stimulus. We first detected amylin mRNA at $13 \mathrm{wk}$ gestation, in agreement with initial amylin immunoreactivity at $13 \mathrm{wk}(44)$, considerably later than insulin immunoreactivity, which occurred at 9 wk gestation. In the previously published immunohistochemical study, the percentage of amylin-positive insulin cells increased with gestational age and reached nearly $100 \%$ in the adult pancreas (44). In accordance with this, we observed an approximately 10 -fold increase in amylin transcripts in the adult compared with the fetal pancreas.

The amniotic fluid swallowed by the fetus acts as a stimulus for the developing exocrine pancreas. The nonparallel appearance of secretory proteins in the fetal exocrine pancreas has previously been reported $(39,45$, 46), perhaps reflecting the adaptive ability of the pancreas to the changing composition of the amniotic fluid. Inasmuch as amniotic fluid is devoid of starch, it is not surprising that amylase activity has not been detected in the fetal pancreas $(45,46)$. In fact, amylase was not detectable in the neonatal pancreas either $(46,47)$, but did increase during the first year (48). Consistent with this developmental process, we were unable to detect expression of the amylase gene in the fetal pancreas, although high levels of amylase transcripts were detected in the pancreas of the 11-mo-old child and the adult.

In summary, we measured transcriptional expression of various endocrine and exocrine genes in the human pancreas during development. Our results confirmed earlier immunohistochemical and enzymatic studies of the islet hormones, amylin, and amylase. In addition, we showed that the reg gene is developmentally regulated in the human fetal pancreas, with an abrupt increase in expression at $16 \mathrm{wk}$ gestation, and that the gene localizes exclusively to the pancreatic acinar cells. Furthermore, we showed that the GLUT-1, GLUT-2, and glucokinase genes are expressed early in human pancreatic development. This study establishes a baseline of information on the temporal transcriptional regulation of pancreasspecific genes during pancreatic ontogeny and contributes to the basic research and knowledge required before undertaking human fetal tissue transplantation as a means to treat insulin-dependent diabetes.

Acknowledgments. The authors are grateful to AnaMaria Gonzalez for her expert advice and assistance with the in situ hybridization analysis and to Gillian Beattie and Fred Levine for helpful criticisms of the manuscript. We thank the following investigators for supplying us with the probes used in the RNase protection assay: $P$. Miettinen, D. Drucker, D. Bergsma, D. Steiner, and H. Okamoto.

\section{REFERENCES}

1. Like AA, Orci L 1972 Embryogenesis of the human pancreatic islets: a light and electron microscopic study. Diabetes 21(suppl 2):511-534

2. Clark A, Grant AM 1983 Quantitative morphology of endocrine cells in human fetal pancreas. Diabetologia 25:31-35

3. Stefan Y, Grasso S, Perrelet A, Orci L 1983 A quantitative immunofluorescent study of the endocrine cell populations in the developing human pancreas. Diabetes 32:293-301

4. Von Dorsche HH, Falt K, Titlbach M, Reiher H, Hahn H-J, Falkmer S 1989 Immunohistochemical, morphometric and ultrastructural investigations of the early development of insulin, somatostatin, glucagon and PP cells in foetal human pancreas. Diabetes Res 12:551-556

5. Gittes GK, Rutter WR 1992 Onset of cell-specific gene expression in the developing mouse pancreas. Proc Natl Acad Sci USA 89:1128-1132

6. Otonkoski T, Andersson S, Knip M, Simell O 1988 Maturation of insulin response to glucose during human fetal and neonatal development. Diabetes 37:286-291

7. Fukumoto H, Seino S, Imura H, Seino Y, Eddy RL, Fukushima Y, Byers MG, Shows TB, Bell GI 1988 Sequence, tissue distribution, and chromosomal localization of mRNA encoding a human glucose transporter-like protein. Proc Natl Acad Sci USA 85:5434-5438

8. Thorens B, Sarkar HK, Kaback HR, Lodish HF 1988 Cloning and functional expression in bacteria of a novel glucose transporter present in liver, intestine, kidney, and $\beta$-pancreatic islet cells. Cell 55:281-290

9. Devaskar SU, Mueckler MM 1992 The mammalian glucose transporters. Pediatr Res 31:1-13

10. Orci L, Thorens B, Ravazzola M, Lodish HF 1989 Localization of the pancreatic beta cell glucose transporter to specific plasma membrane domains. Science 245:295-297

11. Terazono K, Yamamoto H, Takasawa S, Shiga K, Yonemura Y, Tochino Y, Okamoto H 1988 A novel gene activated in regenerating islets. J Biol Chem 263:2111-2114

12. Newgard CB, Hughes S, Chen L, Okamoto H, Milburn JL 1989 The reg gene is preferentially expressed in the exocrine pancreas during islet regeneration. Diabetes 38:49A(abstr)

13. Miyaura C, Chen L, Appel M, Alam T, Inman L, Hughes SD, Milburn JL, Unger RH, Newgard CB 1991 Expression of reg/PSP, a pancreatic exocrine gene: relationship to changes in islet $\beta$-cell mass. Mol Endocrinol 5:226-234 
14. Francis PJ, Southgate JL, Wilkin TJ, Bone AJ 1992 Expression of an islet regenerating (reg) gene in isolated rat islets: effects of nutrient and nonnutrient growth factors. Diabetologia 35:238-242

15. Kimura N, Yonekura H, Okamoto H, Nagura H 1992 Expression of human regenerating gene mRNA and its product in normal and neoplastic human pancreas. Cancer 70:1857-1863

16. Sambrook J, Fritsch EF, Maniatis T 1989 Molecular Cloning: A Laboratory Manual. Cold Spring Harbor Laboratory Press, Cold Spring Harbor, NY, pp $1.53-1.86$

17. Bell GI, Swain WF, Pictet R, Cordell B, Goodman HM, Rutter WJ 1979 Nucleotide sequence of a cDNA clone encoding human preproinsulin. Nature 282:525-527

18. Drucker DJ, Asa S 1988 Glucagon gene expression in vertebrate brain. J Biol Chem 27:13475-13478

19. Shen L-P, Rutter WJ 1984 Sequence of the human somatostatin I gene. Science 224:168-170

20. Haendler B, Hofer-Warbinek R, Hofer E 1987 Complementary DNA for human T-cell cyclophilin. Embo J 6:947-950

21. Gumucio DL, Wiebauer K, Caldwell RM, Samuelson LC, Meisler MH 1988 Concerted evolution of human amylase genes. Mol Cell Biol 8:1197-1205

22. Mueckler M, Caruso C, Baldwin SA, Panico M, Blench I, Morris HR, Allard WJ, Lienhard GE, Lodish HF 1985 Sequence and structure of a human glucose transporter. Science 229:941-945

23. Melton DA, Krieg PA, Rebagliati MR, Maniatis T, Zinn K, Green MR 1984 Efficient in vitro synthesis of biologically active RNA and RNA hybridization probes from plasmids containing a bacteriophage SP6 promoter. Nucleic Acids Res 12:7035-7056

24. Chomczynski P, Sacchi N 1987 Single-step method of RNA isolation by guanidinium thiocyanate-phenol-chloroform extraction. Anal Biochem 162:156-159

25. Singer PA, Balderas RS, Theofilopoulos AN 1990 Thymic selection defines multiple T cell receptor V $\beta$ "repertoire phenotypes" at the CD4/CD8 subset level. EMBO J 9:3641-3648

26. Simmons DM, Arriza JL, Swanson LW 1989 A complete protocol for in situ hybridization of messenger RNAs in brain and other tissues with radiolabeled single-stranded RNA probes. J Histotechnol 12:169-181

27. Erber WN, Mason DY 1987 Immunoalkaline phosphatase labeling of terminal transferase in hematologic samples. Am J Clin Pathol 88:43-50

28. Seino $Y$, Yamamoto T, Inoue $K$, Imamura M, Kadowaki S, Kojima H, Fujikawa J, Imura H 1993 Abnormal facilitative glucose transporter gene expression in human islet cell tumors. J Clin Endocrinol Metab 76:75-78

29. Koranyi LI, Tanizawa Y, Welling CM, Rabin DU, Permutt MA 1992 Human islet glucokinase gene: isolation and sequence analysis of full-length cDNA. Diabetes 41:807-811

30. Tanizawa Y, Koranyi LI, Welling CM, Permutt MA 1991 Human liver glucokinase gene: cloning and sequence determination of two alternatively spliced cDNAs. Proc Natl Acad Sci USA 88:7294-7297

31. Chen L, Alam T, Johnson JH, Hughes S, Newgard CB, Unger RH 1993 Regulation of $\beta$-cell glucose transporter gene expression. Proc Natl Acad Sci USA 87:4088-4092
32. Thorens B, Weir GC, Leahy JL, Lodish HF, Bonner-Weir S 1990 Reduced expression of the liver/beta cell glucose transporter isoform in glucoseinsensitive pancreatic beta cells of diabetic rats. Proc Natl Acad Sci USA 87:6492-6496

33. Hughes SD, Quaade C, Milburn JL, Cassidy L, Newgard CB 1991 Expression of normal and novel glucokinase mRNAs in anterior pituitary and islet cells. J Biol Chem 266:4521-4530

34. Tal M, Liang Y, Najafi H, Lodish HF, Matschinsky FM 1992 Expression and function of GLUT-1 and GLUT-2 glucose transporter isoforms in cells of cultured rat pancreatic islets. J Biol Chem 267:17241-17247

35. Meglasson MD, Matschinsky FM 1986 Pancreatic islet glucose metabolism and regulation of insulin secretion. Diabetes Metab Rev 2:163-214

36. Matschinsky F, Liang Y, Kesavan P, Wang L, Froguel P, Velho G, Cohen D, Permutt MA, Tanizawa Y, Jetton TL, Niswender K, Magnuson MA 1993 Glucokinase as pancreatic $\beta$ cell glucose sensor and diabetes gene. J Clin Invest 92:2092-2098

37. Terazono $\mathrm{K}$, Uchiyama $\mathrm{Y}$, Ide $\mathrm{M}$, Watanabe $\mathrm{T}$, Yonekura $\mathrm{H}$, Yamamoto $\mathrm{H}$, Okamoto H 1990 Expression of reg protein in rat regenerating islets and its co-localization with insulin in the beta cell secretory granules. Diabetologia 33:250-252

38. Watanabe $T$, Yonekura $H$, Terazono $K$, Yamamoto $H$, Okamoto $H 1990$ Complete nucleotide sequence of human reg gene and its expression in normal and tumoral tissues. J Biol Chem 265:7432-7439

39. Carrere J, Figarella-Branger D, Senegas-Balas F, Figarella C, Guy-Crotte O 1992 Immunohistochemical study of secretory proteins in the developing human exocrine pancreas. Differentiation 51:55-60

40. Patthy L 1988 Homology of human pancreatic stone protein with animal lectins. Biochem J 253:309-311

41. Peterson TE 1988 The amino terminal domain of thrombomodulin and PSP are homologous with lectins. FEBS Lett 231:51-53

42. Johnson KH, O'Brien TD, Hayden DW, Jordan K, Ghobrial HKG, Mahoney WC, Westermark P 1988 Immunolocalization of islet amyloid polypeptide (IAPP) in pancreatic beta cells by means of peroxidase-antiperoxidase (PAP) and protein A-gold techniques. Am J Pathol 130:1-8

43. Lukinius A, Wilander E, Westermark GT, Engstrom U, Westermark P 1989 Co-localization of islet amyloid polypeptide and insulin in the B cell secretory granules of the human pancreatic islet. Diabetologia 32:240-244

44. In't Veld PA, Zhang F, Madsen OD, Kloppel G 1992 Islet amyloid polypeptide immunoreactivity in the human fetal pancreas. Diabetologia 35:272-276

45. Track NS, Creutzfeldt C, Bokermann M 1975 Enzymatic, functional and ultrastructural development of the exocrine pancreas-II. The human pancreas. Comp Biochem Physiol 51A:95-100

46. Fukayama M, Ogawa M, Hayashi Y, Koike M 1986 Development of human pancreas. Differentiation 31:127-133

47. Lebenthal E, Lee PC 1980 Development of functional response in human exocrine pancreas. Pediatrics 66:556-560

48. Hadorn B, Zoppi G, Shmerling DH, Prader A, Mcintyre 1, Anderson CM 1968 Quantitative assessment of exocrine pancreatic function in infants and children. J Pediatr 73:39-50 